\title{
Responses of Creeping Bentgrass to Salt Stress during In Vitro Germination
}

\author{
Sheng Wang and Qi Zhang ${ }^{1}$ \\ Department of Plant Sciences, North Dakota State University, P.O. Box \\ 6050, Fargo, ND 58108
}

Additional index words. Agrostis stolonifera, salinity, $\mathrm{NaCl}$

\begin{abstract}
Many golf courses and turfgrass managers use recycled water, which contains high salts, as part or a sole irrigation source to lower costs and comply with governmental restrictions on water use. High salinity negatively affects turfgrass performance. Using salt-tolerant species or cultivars is one the most effective methods to address salinity problems. Twenty-six commercially available creeping bentgrass (Agrostis stolonifera) cultivars were evaluated for salt tolerance during in vitro germination on $1 \%$ agar media supplemented with $\mathrm{NaCl}$ at $0,5,10,15$, or $20 \mathrm{~g} \cdot \mathrm{L}^{-1}$ at $25 / 15^{\circ} \mathrm{C}$ (day/night) under fluorescent light $\left(36 \mu \mathrm{mol} \cdot \mathrm{s}^{-1} \cdot \mathrm{m}^{-2}\right)$ with an 8- to16-h photoperiod. Significant variations in salinity tolerance were observed among the cultivars. Final germination rate (FGR, \%) and daily germination rate (DGR, \%/d) decreased linearly or quadratically as salinity levels increased. 'Declaration', 'Seaside II', 'T-1', and 'Bengal' were the most salt-tolerant, requiring salt levels at or greater than 16.0 and $10.0 \mathrm{~g} \cdot \mathrm{L}^{-1}$, respectively, to reduce $\mathrm{FGR}$ and DGR by $50 \%$. In contrast, 'Tyee', 'Kingpin', and 'SR1150' required average salinity levels of 11.6 and $6.5 \mathrm{~g} \cdot \mathrm{L}^{-1}$ to cause $50 \%$ reduction in FGR and DGR, respectively, showing that they were the least salt-tolerant cultivars. The largest difference between FGR (1.9\%) and DGR $(26.2 \%)$ reduction under saline conditions was observed at $5 \mathrm{~g} \cdot \mathrm{L}^{-1}$, indicating that DGR was more sensitive to salinity changes than FGR. Therefore, DGR might be a more reliable method to be used for salt selection.
\end{abstract}

Creeping bentgrass (Agrostis stolonifera) is widely used on golf course putting greens, fairways, and other intensively managed turf facilities in northern climates because of its fine leaf texture, high density, and excellent tolerance of low mowing and freezing temperature. Frequent irrigation is required for creeping bentgrass to remain functional and maintain its aesthetic qualities under intense use. However, limited water resources and rapid suburban expansion have led to the restricted use of potable water in many communities.

Recycled water (effluent or reclaimed) is the only water source with increasing availability and may be an alternative to potable water for turfgrass irrigation (Qian and Harivandi, 2008). To date, $\approx 13 \%$ of golf courses in the United States are using reclaimed water for irrigation, most of which are in the metropolitan areas in the southwest (Qian and Harivandi, 2008). For example, turf facilities exceeding 10 acres in Arizona and all turf land in California are required to use recycled water for irrigation when available (Arizona Department of Water Resources, 2008; California State Water Resources Control Board, 2010). However, excessive salts in recycled water may cause salinity/sodicity damage on turfgrass (Qian and Harivandi, 2008). Qian and Mecham (2005) reported an increase of soil electrical conductivity (EC), sodium absorption ratio, and levels of $\mathrm{pH}$, sodium, boron, and phosphorus on golf fairways after long-term (4 to 33 years) use of

Received for publication 21 June 2010. Accepted for publication 26 Aug. 2010.

${ }^{1}$ To whom reprint requests should be addressed; e-mail qi.zhang.1@ndsu.edu. recycled water. Turfgrass loss was also observed on courses subjected to long-term effluent irrigation (Qian and Mecham, 2005). Use of salt-tolerant species/cultivars is one of the most economically efficient cultural practices to help remedy soil salinity effects on turf (Harivandi, 2007).

Limited information is available on the salinity tolerance of bentgrass cultivars. Younger et al. (1967) reported that soil EC levels at 9 to $26 \mathrm{dS} \cdot \mathrm{m}^{-1}$ caused a $50 \%$ shoot reduction in seven creeping bentgrass cultivars, and their salinity tolerance decreased in the following order: 'Seaside', 'Arlington', 'Pennlu', 'Old Orchard', 'Congressional', 'Cohansey', and 'Penncross'. McCarty and Dudeck (1993) compared salt tolerance of eight cultivars based on germination reduction. They found that 'Streaker' redtop (A. alba) and 'Seaside' creeping bentgrass were the most salt-tolerant; 'Kingstown' velvet bentgrass (A. canina) and 'Highland' and 'Exeter' colonial bentgrass (A. tenuis) expressed moderate salt tolerance; and 'Pennlinks', 'Penncross', and 'Penneagle' creeping bentgrass were the least salt-tolerant In the latest comparison of salinity tolerance in mature plants of 35 bentgrass cultivars, 'Mariner', 'Grand Prix', 'Seaside', and 'Seaside II' were considered the most salt-tolerant followed by 'L-93', 'Penn G-2', '18th Green', and 'Syn 96-1', whereas 'Avalon' (velvet), 'Ambrosia' (colonial), 'SR1119', 'Regent', 'Putter', 'Penncross', and 'Penn G-6' were salt-sensitive based on shoot and root reduction under saline conditions (Marcum, 2001). A new generation of improved creeping bentgrass cultivars were made commercially available in the last decade, including 'Declaration' with high dollar spot (Sclerotinia homoeo- carpa) tolerance (NTEP, 2008a, 2008b), 'Independence' with high drought tolerance (McCann and Huang, 2008), 'T-1' and 'Alpha' with high compatibility over annual bluegrass (Poa annua) (Brede, 2007), and '007' and 'Tyee' with high overall quality (NTEP, 2008b). Limited information is available on the salinity tolerance of the aforementioned new creeping bentgrass cultivars. The objective of this study was to compare the salinity tolerance of commonly used commercial creeping bentgrass cultivars, including the new releases, based on germination reduction at the seedling stage under a controlled environment. This research will provide the turf managers with useful information on selecting salt-tolerant creeping bentgrass cultivars.

\section{Materials and Methods}

Seeds of 26 commercial creeping bentgrasses (Table 1) were surface-sterilized using the method of Dai et al. (2009) with minor modifications. Seeds were soaked in $95 \%$ ethanol for $1 \mathrm{~min}$ and submerged in $2 \%(\mathrm{v} / \mathrm{v})$ sodium hypochlorite solution for $20 \mathrm{~min}$. Seeds were then rinsed three times with deionized/distilled water $\left(\mathrm{ddH}_{2} \mathrm{O}\right)$. Sterilized seeds of each cultivar were placed in 100-mmdiameter $\times 15$-mm petri dishes containing 20 $\mathrm{mL}$ of $1 \%$ agar (Sigma-Aldrich Co., St. Louis, MO) supplemented with $0,5,10,15$, or $20 \mathrm{~g} \cdot \mathrm{L}^{-1} \mathrm{NaCl}$. The medium was autoclaved at $121^{\circ} \mathrm{C}$ and $103 \mathrm{kPa}$ for $25 \mathrm{~min}$ before being poured into petri dishes. Dishes with sterilized seeds were placed in an incubator (model I-35 VL; Percival Scientific, Perry, IA) at $25 / 15^{\circ} \mathrm{C}$ (day/night) under fluorescent light (36 $\mu \mathrm{mol} \cdot \mathrm{s}^{-1} \cdot \mathrm{m}^{-2}$ ) with an 8- tol6-h photoperiod (Association of Official Seed Analysts, 2004). Each dish contained 56 seeds and each treatment contained three dishes (replications). This experiment was conducted as a completely randomized design, consisting of three replications of a $26 \times 5$ factorial arrangement with cultivars and salinity levels, respectively.

The number of seeds germinating per dish was recorded three times a week for 4 weeks. The petri dishes were rotated after each counting to minimize the shelf effect (Dai et al., 2009). In this study, seed germination was defined as an emerged shoot visible under $2 \times$ magnification (McCarty and Dudeck, 1993) Final germination rate was calculated using FGR $(\%)=100 \times\left[\left(\sum n\right) / 56\right]$ and DGR $(\% / \mathrm{d})=100 \times\left[\sum(n / D)\right] / 56$, where $n$ was the number of newly germinated seeds at each counting and $D$ was the number of days accumulated up to that counting (Dai et al., 2009). The experiment was conducted from 17 July to 20 Aug. (Study 1) and repeated from 16 Aug. to 13 Sept. 2009 (Study 2).

To provide an accurate indication of salinity tolerance, FGR was standardized based on the method of Teolis et al. (2009), in which the value of FGR for a control $\left(0 \mathrm{~g} \cdot \mathrm{L}^{-1} \mathrm{NaCl}\right)$ was $100 \%$. The higher the ratio of FGR under saline conditions to FGR in control, the greater the salinity tolerance. Final germination rate and DGR were transformed using arcsine and square root, respectively, to 
meet the constant variance assumption in the analysis of variance (Dai et al., 2009). All data were subjected to PROC GLM (SAS, 2004). Means were separated with Fisher's protected least significant difference at $P \leq 0.05$. Regression analyses (PROC GLM) within cultivars were conducted to predict salinity levels, which caused $10 \%, 25 \%$, or $50 \%$ reduction in FGR and DGR (SAS, 2004).

\section{Results and Discussion}

Final germination rate and DGR were both affected by the study $\times$ cultivar $\times$ salinity interaction. However, the $F$-test revealed that the two studies were homogeneous (data not shown). Furthermore, rankings of FGR and DGR pooled across the cultivars and salinity levels were comparable in the two studies (data not shown). Thus, the three-way interaction was more likely the result of the close ranking of relative salinity tolerance in the large number of cultivars evaluated in the present studies. Consequently, data from the two studies were pooled together for further analysis. Transformation did not affect the statistical results or the ranking of relative salinity tolerance in the cultivars. To minimize difficulty and confusion in data interpretation caused by data transformation, untransformed data are presented.

Final germination rate decreased quadratically in all cultivars, except 'Tyee', 'Kingpin', and 'SR1150', which had a linear decrease with the increase of $\mathrm{NaCl}$ levels (Table 1). Based on the reduction of FGR, the 26 cultivars can be divided into three groups (Table 1). 'Declaration', 'Seaside II', 'T-1', 'Independence', and 'Bengal' (Group 1) required the highest salinity levels $\left(\mathrm{NaCl}=16.0 \mathrm{~g} \cdot \mathrm{L}^{-1}\right.$ or greater) to reduce FGR by $50 \%$. However, an average of $11.6 \mathrm{~g} \cdot \mathrm{L}^{-1} \mathrm{NaCl}$ would result in a $50 \%$ reduction of FGR in 'Tyee', 'Kingpin', and 'SR1150' (Group 3) (Table 1). Under the highest salinity level $\left(20 \mathrm{~g} \cdot \mathrm{L}^{-1}\right)$, 'Declaration', 'Seaside II', 'Bengal', and 'T-1' yielded 10\% of FGR, whereas no germination was observed in Group 3 under the same salt level (Fig. 1). McCarty and Dudeck (1993) used the same method to predict salt tolerance of seven bentgrass cultivars. They predicted a $50 \%$ FGR reduction at $15 \mathrm{~g} \cdot \mathrm{L}^{-1}$ in 'Seaside', comparable to that in 'Seaside II' in the present study, and 'Penncross' was more salt-sensitive than 'Seaside'. Similarly, 'Seaside II' showed higher salt tolerance than 'Penncross' in the present study. However, Dai et al. (2009) reported similar FGR and DGR in 'Penncross' and 'Seaside II' under saline conditions, indicating similar salt tolerance. Different seed sources might be the cause of this inconsistent result.

Daily germination rate decreased linearly or quadratically with increasing saline concentration (Table 2). Salt tolerance of 26 creeping bentgrass cultivars of DGR was ranked similarly to the result of FGR. 'Declaration', 'Seaside II', 'T-1', and 'Bengal' were the most salt-tolerant and 'A-4', 'Alister', 'SR1150', 'Tyee', and 'Kingpin' were the least salt-tolerant (Table 2; Fig. 2). This study

Table 1 . Predicted salinity levels to reduce $10 \%, 25 \%$, or $50 \%$ final germination rate in 26 commercial creeping bentgrass cultivars.

\begin{tabular}{|c|c|c|c|c|c|c|}
\hline \multirow[b]{3}{*}{ Cultivar } & \multirow[b]{3}{*}{ Regression } & \multirow[b]{3}{*}{$r^{2}$} & \multicolumn{3}{|c|}{ FGR $^{z}$ reduction $(\%)$} & \multirow[b]{3}{*}{ Group no } \\
\hline & & & 10 & 25 & 50 & \\
\hline & & & \multicolumn{3}{|c|}{$\left(g \cdot L^{-1}\right)$} & \\
\hline Declaration & $y=97.7+3.12 x-0.36 x^{2}$ & $0.95^{* * *}$ & $10.72 \mathrm{a}^{\mathrm{y}}$ & $13.46 \mathrm{a}$ & $16.74 \mathrm{a}$ & 1 \\
\hline Seaside II & $y=96.1+3.38 x-0.38 x^{2}$ & $0.94 * * *$ & $10.10 \mathrm{ab}$ & $13.16 \mathrm{a}$ & $16.42 \mathrm{a}$ & 1 \\
\hline $\mathrm{T}-1$ & $y=98.9+2.84 x-0.36 x^{2}$ & $0.95 * * *$ & $10.32 \mathrm{ab}$ & $13.03 \mathrm{a}$ & $16.29 \mathrm{ab}$ & 1 \\
\hline Independence & $y=98.2+3.64 x-0.41 x^{2}$ & $0.97 * * *$ & $10.72 \mathrm{a}$ & $13.16 \mathrm{a}$ & $16.14 \mathrm{ab}$ & 1 \\
\hline Bengal & $y=101+2.63 x-0.36 x^{2}$ & $0.95 * * *$ & $10.12 \mathrm{ab}$ & $12.78 \mathrm{ab}$ & $16.00 \mathrm{ab}$ & 1 \\
\hline Memorial & $y=99.2+2.79 x-0.38 x^{2}$ & $0.87 * * *$ & $9.57 \mathrm{a}-\mathrm{c}$ & $12.28 \mathrm{a}-\mathrm{c}$ & $15.48 \mathrm{bc}$ & 2 \\
\hline Century & $y=101+1.40 x-0.32 x^{2}$ & $0.94 * * *$ & $8.43 \mathrm{c}-\mathrm{e}$ & $11.49 \mathrm{c}-\mathrm{e}$ & $15.07 \mathrm{~cd}$ & 2 \\
\hline MacKenzie & $y=101+1.85 x-0.35 x^{2}$ & $0.96 * * *$ & $8.81 \mathrm{~b}-\mathrm{d}$ & $11.63 \mathrm{~b}-\mathrm{d}$ & $14.96 \mathrm{c}-\mathrm{e}$ & 2 \\
\hline Alpha & $y=101+1.38 x-0.32 x^{2}$ & $0.96 * * *$ & $8.31 \mathrm{c}-\mathrm{e}$ & $11.34 \mathrm{c}-\mathrm{f}$ & $14.88 \mathrm{c}-\mathrm{f}$ & 2 \\
\hline Crenshaw & $y=101+1.09 x-0.31 x^{2}$ & $0.96^{* * *}$ & $8.01 \mathrm{c}-\mathrm{e}$ & $11.11 \mathrm{c}-\mathrm{g}$ & $14.73 \mathrm{c}-\mathrm{f}$ & 2 \\
\hline Pennlinks II & $y=102+0.99 x-0.32 x^{2}$ & $0.95 * * *$ & $7.94 \mathrm{~d}-\mathrm{g}$ & $10.96 \mathrm{~d}-\mathrm{h}$ & $14.51 \mathrm{~d}-\mathrm{g}$ & 2 \\
\hline Southshore & $y=103+0.84 x-0.31 x^{2}$ & $0.94 * * *$ & $7.93 \mathrm{~d}-\mathrm{g}$ & $10.90 \mathrm{~d}-\mathrm{i}$ & $14.46 \mathrm{~d}-\mathrm{h}$ & 2 \\
\hline Putter & $y=101-0.41 x-0.22 x^{2}$ & $0.93 * * *$ & $6.09 \mathrm{~h}$ & $9.84 \mathrm{~h}-\mathrm{k}$ & $14.18 \mathrm{e}-\mathrm{i}$ & 2 \\
\hline Imperial & $y=103-0.16 x-0.25 x^{2}$ & $0.92 * * *$ & $6.90 \mathrm{~h}$ & $10.22 \mathrm{f}-\mathrm{j}$ & $14.17 \mathrm{e}-\mathrm{i}$ & 2 \\
\hline Penncross & $y=102+0.26 x-0.28 x^{2}$ & $0.93 * * *$ & $7.06 \mathrm{e}-\mathrm{h}$ & $10.30 \mathrm{e}-\mathrm{j}$ & $14.08 \mathrm{f}-\mathrm{i}$ & 2 \\
\hline L-93 & $y=103-0.43 x-0.25 x^{2}$ & $0.92 * * *$ & $6.55 \mathrm{f}-\mathrm{h}$ & $9.90 \mathrm{~g}-\mathrm{k}$ & $13.87 \mathrm{~g}-\mathrm{k}$ & 2 \\
\hline 007 & $y=98.8+0.12 x-0.26 x^{2}$ & $0.82 * * *$ & $5.96 \mathrm{~h}-\mathrm{i}$ & $9.69 \mathrm{i}-\mathrm{k}$ & $13.82 \mathrm{~g}-\mathrm{k}$ & 2 \\
\hline Penn A-1 & $y=104-0.40 x-0.26 x^{2}$ & $0.92 * * *$ & $6.69 \mathrm{f}-\mathrm{h}$ & $9.92 \mathrm{~g}-\mathrm{k}$ & $13.80 \mathrm{~g}-\mathrm{k}$ & 2 \\
\hline Alister & $y=104-0.93 x-0.22 x^{2}$ & $0.94 * * *$ & $6.19 \mathrm{~h}$ & $9.59 \mathrm{jk}$ & $13.77 \mathrm{~g}-\mathrm{k}$ & 2 \\
\hline A-4 & $y=104-0.95 x-0.22 x^{2}$ & $0.93 * * *$ & $6.15 \mathrm{~h}$ & $9.52 \mathrm{jk}$ & $13.62 \mathrm{~h}-\mathrm{k}$ & 2 \\
\hline Crystal bluelinks & $y=104-0.75 x-0.24 x^{2}$ & $0.92 * * *$ & $6.36 \mathrm{gh}$ & $9.60 \mathrm{jk}$ & $13.55 \mathrm{i}-\mathrm{k}$ & 2 \\
\hline Penn G-6 & $y=103-1.29 x-0.20 x^{2}$ & $0.91 * * *$ & $5.63 \mathrm{hi}$ & $9.04 \mathrm{jk}$ & $13.28 \mathrm{jk}$ & 2 \\
\hline LS-44 & $y=103-1.31 x-0.21 x^{2}$ & $0.94 * * *$ & $5.51 \mathrm{~h}-\mathrm{j}$ & $8.95 \mathrm{k}$ & $13.18 \mathrm{k}$ & 2 \\
\hline Tyee & $y=113-5.79 x$ & $0.87^{* * *}$ & $4.44 \mathrm{jk}$ & 7.541 & 11.851 & 3 \\
\hline Kingpin & $y=111-5.67 x$ & $0.90 * * *$ & $3.85 \mathrm{k}$ & 7.031 & 11.561 & 3 \\
\hline SR1150 & $y=111-5.71 x$ & $0.90 * * *$ & $4.03 \mathrm{jk}$ & 7.041 & 11.461 & 3 \\
\hline
\end{tabular}

${ }^{\mathrm{z}}$ Final germination rate (FGR) under saline conditions was expressed as a percentage of control $\left(0 \mathrm{~g} \cdot \mathrm{L}^{-1}\right.$ $\mathrm{NaCl}$ ) of each cultivar.

${ }^{\mathrm{y}}$ Means followed by the same letter in each column are not significantly different at the 0.05 level of probability.

***Significant at the 0.001 level of probability.

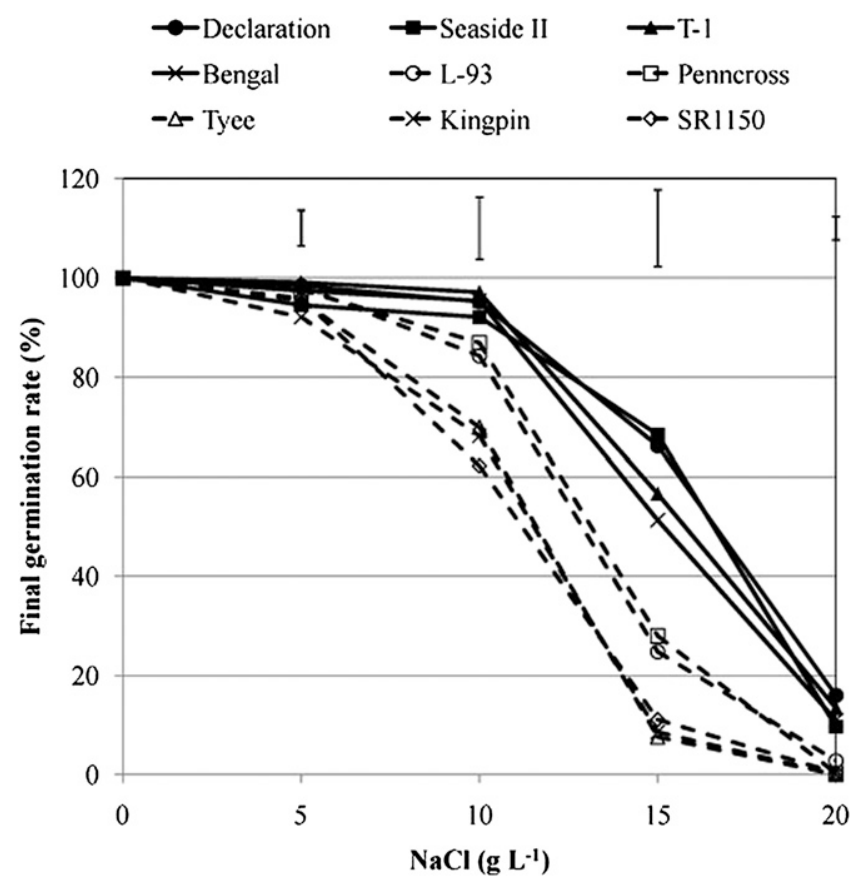

Fig. 1. Final germination rate (\%) of nine representative creeping bentgrass cultivars, Declaration, Seaside II, T-1, and Bengal (highly salt-tolerant), L-93, and Penncross (moderate salt-tolerant) and Tyee, Kingpin, and SR1150 (salt-sensitive) with increasing NaCl concentrations $\left(\mathrm{g} \cdot \mathrm{L}^{-1}\right)$. Final germination rate under saline conditions was expressed as a percentage of control $\left(0 \mathrm{~g} \cdot \mathrm{L}^{-1} \mathrm{NaCl}\right)$ for each cultivar. Individual data points were the means of six replications in two studies. Vertical bars represent least significant difference at $P \leq 0.05$.

showed that even for cultivars in Group 3 (with the least salt tolerance), DGR was only reduced by $10 \%$ when salinity level reached
$1.2 \mathrm{~g} \cdot \mathrm{L}^{-1}$, indicating that creeping bentgrass has moderate tolerance to salt stress. Based on the predicted values that would cause a 
Table 2. Predicted salinity levels to reduce $10 \%, 25 \%$, or $50 \%$ daily germination rate (DGR, \%/d) in 26 commercial creeping bentgrass cultivars.

\begin{tabular}{|c|c|c|c|c|c|c|}
\hline \multirow[b]{3}{*}{ Cultivar } & \multirow[b]{3}{*}{ Regression } & \multirow[b]{3}{*}{$r^{2}$} & \multicolumn{3}{|c|}{ DGR reduction $(\% / d)$} & \multirow[b]{3}{*}{ Group no } \\
\hline & & & 10 & 25 & 50 & \\
\hline & & & \multicolumn{3}{|c|}{$\left(\mathrm{g} \cdot \mathrm{L}^{-1}\right)$} & \\
\hline Declaration & $y=21.6-1.03 x$ & $0.98 * * *$ & $2.70 \mathrm{a}^{\mathrm{z}}$ & $5.87 \mathrm{a}$ & $10.95 \mathrm{a}$ & 1 \\
\hline Seaside II & $y=26.1-1.25 x$ & $0.97 * * *$ & $2.56 \mathrm{ab}$ & $5.75 \mathrm{a}$ & $10.73 \mathrm{ab}$ & 1 \\
\hline $\mathrm{T}-1$ & $y=22.5-1.09 x$ & $0.97 * * *$ & $2.14 \mathrm{a}-\mathrm{d}$ & $5.13 \mathrm{ab}$ & $10.07 \mathrm{a}-\mathrm{c}$ & 1 \\
\hline Bengal & $y=19.2-0.96 x$ & $0.89 * * *$ & $2.15 \mathrm{a}-\mathrm{d}$ & $5.08 \mathrm{ab}$ & $9.98 \mathrm{a}-\mathrm{c}$ & 1 \\
\hline Independence & $y=22.6-1.14 x$ & $0.94 * * *$ & $2.08 \mathrm{a}-\mathrm{d}$ & $4.92 \mathrm{a}-\mathrm{c}$ & $9.66 \mathrm{~b}-\mathrm{d}$ & 2 \\
\hline Memorial & $y=17.8-0.91 x$ & $0.93 * * *$ & $2.03 \mathrm{~b}-\mathrm{e}$ & $4.78 \mathrm{~b}-\mathrm{d}$ & $9.51 \mathrm{~b}-\mathrm{d}$ & 2 \\
\hline Century & $y=20.9-1.09 x$ & $0.97 * * *$ & $2.13 \mathrm{a}-\mathrm{d}$ & $4.67 \mathrm{~b}-\mathrm{e}$ & $9.16 \mathrm{c}-\mathrm{e}$ & 2 \\
\hline Crenshaw & $y=21.2-1.11 x$ & $0.97 * * *$ & $2.18 \mathrm{a}-\mathrm{c}$ & $4.70 \mathrm{~b}-\mathrm{e}$ & $9.15 \mathrm{c}-\mathrm{e}$ & 2 \\
\hline Alpha & $y=20.9-1.09 x$ & $0.97 * * *$ & $1.90 \mathrm{c}-\mathrm{e}$ & $4.47 \mathrm{~b}-\mathrm{f}$ & $9.02 \mathrm{c}-\mathrm{e}$ & 2 \\
\hline Southshore & $y=21.0-1.11 x$ & $0.97 * * *$ & $2.12 \mathrm{a}-\mathrm{d}$ & $4.60 \mathrm{~b}-\mathrm{f}$ & $9.00 \mathrm{c}-\mathrm{e}$ & 2 \\
\hline MacKenzie & $y=22.0-1.15 x$ & $0.97 * * *$ & $1.79 \mathrm{c}-\mathrm{f}$ & $4.33 \mathrm{~b}-\mathrm{f}$ & $8.85 \mathrm{c}-\mathrm{f}$ & 2 \\
\hline Imperial & $y=17.9-1.18 x+0.01 x^{2}$ & $0.97 * * *$ & $1.90 \mathrm{c}-\mathrm{e}$ & $4.29 \mathrm{~b}-\mathrm{f}$ & $8.60 \mathrm{~d}-\mathrm{g}$ & 2 \\
\hline Penncross & $y=22.5-1.50 x+0.02 x^{2}$ & $0.97 * * *$ & $1.86 \mathrm{c}-\mathrm{e}$ & $4.23 \mathrm{~b}-\mathrm{f}$ & $8.51 \mathrm{~d}-\mathrm{g}$ & 2 \\
\hline Pennlinks II & $y=21.8-1.51 x+0.02 x^{2}$ & $0.98 * * *$ & $1.74 \mathrm{c}-\mathrm{f}$ & $4.04 \mathrm{c}-\mathrm{g}$ & $8.25 \mathrm{e}-\mathrm{g}$ & 2 \\
\hline L-93 & $y=21.0-1.47 x+0.02 x^{2}$ & $0.97 * * *$ & $1.82 \mathrm{c}-\mathrm{f}$ & $4.08 \mathrm{c}-\mathrm{g}$ & $8.23 \mathrm{e}-\mathrm{g}$ & 2 \\
\hline 007 & $y=19.1-1.37 x+0.02 x^{2}$ & $0.92 * * *$ & $1.74 \mathrm{c}-\mathrm{f}$ & $3.97 \mathrm{c}-\mathrm{g}$ & $8.07 \mathrm{e}-\mathrm{g}$ & 2 \\
\hline Crystal bluelinks & $y=23.3-1.70 x+0.02 x^{2}$ & $0.96 * * *$ & $1.86 \mathrm{c}-\mathrm{e}$ & $4.03 \mathrm{c}-\mathrm{h}$ & $8.02 \mathrm{e}-\mathrm{g}$ & 2 \\
\hline Putter & $y=16.3-1.18 x+0.02 x^{2}$ & $0.98 * * *$ & $1.61 \mathrm{c}-\mathrm{f}$ & $3.85 \mathrm{~d}-\mathrm{h}$ & $8.02 \mathrm{e}-\mathrm{g}$ & 2 \\
\hline Penn A-1 & $y=24.0-1.79 x+0.03 x^{2}$ & $0.97 * * *$ & $1.82 \mathrm{c}-\mathrm{f}$ & $3.98 \mathrm{c}-\mathrm{h}$ & $7.94 \mathrm{e}-\mathrm{g}$ & 2 \\
\hline Penn G-6 & $y=21.2-1.63 x+0.03 x^{2}$ & $0.97 * * *$ & $1.71 \mathrm{c}-\mathrm{f}$ & $3.80 \mathrm{e}-\mathrm{h}$ & $7.71 \mathrm{f}-\mathrm{h}$ & 2 \\
\hline LS-44 & $y=19.7-1.52 x+0.03 x^{2}$ & $0.98 * * *$ & $1.66 \mathrm{c}-\mathrm{f}$ & $3.76 \mathrm{e}-\mathrm{h}$ & $7.65 \mathrm{f}-\mathrm{i}$ & 2 \\
\hline A-4 & $y=22.4-1.73 x+0.03 x^{2}$ & $0.98 * * *$ & $1.55 \mathrm{~d}-\mathrm{f}$ & $3.64 \mathrm{f}-\mathrm{h}$ & $7.56 \mathrm{~g}-\mathrm{j}$ & 3 \\
\hline Alister & $y=15.9-1.28 x+0.2 x^{2}$ & $0.96 * * *$ & $1.66 \mathrm{c}-\mathrm{f}$ & $3.66 \mathrm{f}-\mathrm{h}$ & $7.44 \mathrm{~g}-\mathrm{j}$ & 3 \\
\hline SR 1150 & $y=17.6-1.59 x+0.03 x^{2}$ & $0.97 * * *$ & $1.45 \mathrm{ef}$ & $3.25 \mathrm{gh}$ & $6.69 \mathrm{~h}-\mathrm{j}$ & 3 \\
\hline Tyee & $y=17.1-1.57 x+0.03 x^{2}$ & $0.96 * * *$ & $1.23 \mathrm{f}$ & $3.01 \mathrm{~h}$ & $6.42 \mathrm{ij}$ & 3 \\
\hline Kingpin & $y=18.6-1.74 x+0.04 x^{2}$ & $0.98 * * *$ & $1.23 \mathrm{f}$ & $2.98 \mathrm{~h}$ & $6.32 \mathrm{j}$ & 3 \\
\hline
\end{tabular}

${ }^{\mathrm{z}}$ Means followed by the same letter in each column are not significantly different at the 0.05 level of probability.

***Significant at the 0.001 level of probability.

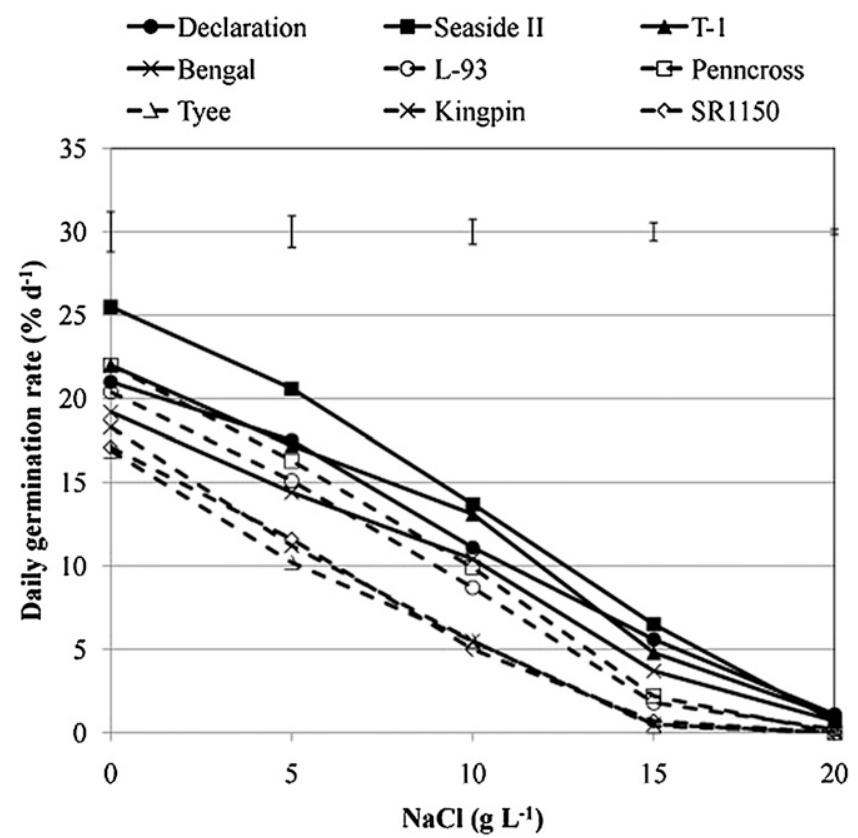

Fig. 2. Daily germination rate $(\% / \mathrm{d})$ of nine representative creeping bentgrass cultivars, Declaration, Seaside II, T-1, and Bengal (highly salt-tolerant); L-93 and Penncross (moderate salt-tolerant); and Tyee, Kingpin, and SR1150 (salt-sensitive) with increasing $\mathrm{NaCl}$ concentrations $\left(\mathrm{g} \cdot \mathrm{L}^{-1}\right)$. Individual data points were the means of six replications in two studies. Vertical bars represent least significant difference at $P \leq 0.05$.

$50 \%$ reduction in DGR, the level of $9 \mathrm{~g} \cdot \mathrm{L}^{-1}$ $\mathrm{NaCl}$ could be used to evaluate salinity tolerance in creeping bentgrass cultivars during germination.

Final germination rate and DGR pooled across cultivars decreased as salinity increased (Table 3). However, DGR had a quicker re-
Table 3. Final germination rate (FGR, \%) and daily germination rate (DGR, \%/d) as affected by salinity.

\begin{tabular}{ccc}
\hline $\mathrm{NaCl}\left(\mathrm{g} \cdot \mathrm{L}^{-1}\right)$ & $\mathrm{FGD}^{\mathrm{z}}(\%)$ & $\mathrm{DGR}(\% / \mathrm{d})$ \\
\hline 0 & $100.0 \mathrm{a}^{\mathrm{y}}$ & $20.2 \mathrm{a}$ \\
5 & $98.1 \mathrm{~b}$ & $14.9 \mathrm{~b}$ \\
10 & $85.5 \mathrm{c}$ & $8.9 \mathrm{c}$ \\
15 & $34.3 \mathrm{~d}$ & $2.5 \mathrm{~d}$ \\
20 & $4.0 \mathrm{e}$ & $0.2 \mathrm{e}$ \\
\hline
\end{tabular}

${ }^{\mathrm{z}}$ Final germination rate under saline conditions was expressed as a percentage of control $\left(0 \mathrm{~g} \cdot \mathrm{L}^{-1} \mathrm{NaCl}\right)$ of each cultivar.

${ }^{y}$ Means followed by the same letter in each row are not significantly different at the 0.05 level of probability.

DGR is more sensitive to salinity change than FGR. Similar findings were observed by Camberato and Martin (2004), Dai et al. (2009), and Marcar (1987). Marcar (1987) reported that ryegrass (Lolium spp.) seeds that failed to germinate in salt solutions exhibited good germination after being transferred to distilled water. Thus, salt solutions primarily delay initiation of germination and extend the time to complete germination rather than causing seed mortality (Marcar, 1987). Because a growing number of golf courses in southern climates are using creeping bentgrass to overseed bermudagrass (Cynodon spp.) greens, fairways, and tees to provide playable surface year-round, selecting bentgrass cultivars with high DGR is critical for a successful overseeding program in the southern United States where effluent and saline water are commonly used or direct ocean spray occurs (McCarty and Dudeck, 1993).

Plant salinity tolerance may vary at different growth stages. Dai et al. (2009) reported that salt sensitivity in greens-type annual bluegrass for seed germination and mature plants was not closely correlated. 'Seaside II' and 'Penncross' exhibited high and moderate salt tolerance in the present study, respectively, during germination. Marcum (2001) reported that mature plants of 'Seaside II' were salttolerant based on tissue and root reduction in a hydroponic study; however, 'Penncross' was ranked as salt-sensitive in the same study. Compared with mature plants, assessment of salinity tolerance during germination is of particular interest. Salinity tolerance at the seedling stage is a heritable trait and can be used as a selection criterion (Ashraf et al., 1987). Furthermore, seeds and young seedlings are more likely to be exposed to high salinity levels near the soil surface, where soluble salts accumulate as a result of evaporation and capillary rise of water during germination than mature plants (Almansouri et al., 2001).

In conclusion, substantial variations in salinity tolerance in 26 commonly used creeping bentgrass cultivars were observed, of which, 'Declaration', 'Seaside II', 'T-1', and 'Bengal' were considered salt-tolerant, whereas 'Tyee', 'SR1150', and 'Kingpin' were salt-sensitive. The results will provide useful information to turfgrass managers in selecting creeping bentgrass cultivars for use in saline conditions as well as turfgrass breeders developing salttolerant cultivars. 


\section{Literature Cited}

Almansouri, M., J.M. Kinet, and S. Lutts. 2001. Effect of salt and osmotic stresses on germination in durum wheat (Triticum durum Desf.). Plant Soil 231:243-254.

Arizona Department of Water Resources. 2008 Evolution and evaluation of the active management area management plans. 5 June 2010. $<$ http://www.azwaterinstitute.org/media/AWI729 megdal.pdf $>$.

Ashraf, M., T. McNeilly, and A.D. Bradshaw. 1987. Selection and heritability of tolerance to sodium chloride in four forage species. Crop Sci. 227:232-234.

Association of Official Seed Analysts. 2004. Rules for testing seeds. Association of Official Seed Analysts, Ithaca, NY.

Brede, A.D. 2007. 'Alpha' and 'T-1' creeping bentgrass, new cultivars for golf. HortScience 42:1301-1302.

California State Water Resources Control Board. 2010. California water code: Porter-cologne water quality control act. Act Provisions on reasonableness and reclamation promotion. Article no. 13550:13552.4

Camberato, J.J. and S.B. Martin. 2004. Salinity slows germination of rough bluegrass. HortScience 39:394-397.

Dai, J., D.R. Huff, and M.J. Schlossberg. 2009. Salinity effects on seed germination and vegetative growth of green-type Poa аппиа relative to other coolseason turfgrass species. Crop Sci. 49:696-703.

Harivandi, A. 2007. Using recycled water on golf courses: As more restrictions are placed on water use, it becomes increasingly important for superintendents to learn the ins and outs of irrigating with recycled water. Golf Course Manage. 75(6):98-108.

Marcum, K.B. 2001. Salinity tolerance of 35 bentgrass cultivars. HortScience 36:374-376.

Marcar, N.E. 1987. Salt tolerance in the genus Lolium (ryegrass) during germination and growth. Aust. J. Agr. Res. 38:297-307.

McCann, S.E. and B. Huang. 2008. Evaluation of drought tolerance and avoidance traits for six creeping bentgrass cultivars. HortScience 43 : 519-524.
McCarty, L.B. and A.E. Dudeck. 1993. Salinity effects on bentgrass germination. HortScience 28:15-17.

NTEP. 2008a. 2003 National bentgrass (fairway/ tee) test. Final report NTEP No. 08-7.

NTEP. 2008b. 2003 National bentgrass (putting green) test. Final report NTEP No. 08-8.

Qian, Y. and A. Harivandi. 2008. Salinity issues associated with recycled wastewater irrigation of turfgrass landscapes, p. 419-429. In: Pessarakli, M. (ed.). Handbook of turfgrass management and physiology. CRC Press, Boca Raton, FL.

Qian, Y.L. and B. Mecham. 2005. Long-term effects of recycled wastewater irrigation on soil chemical properties on golf course fairways. Agron. J. 97:717-721.

SAS. 2004. SAS 9.1.2 qualification tools user's guide. SAS Institute Inc., Cary, NC.

Teolis, I., W. Liu, and E.B. Peffley. 2009. Salinity effects on seed germination and plant growth of guar. Crop Sci. 49:637-642.

Younger, V.B., O.R. Lunt, and F. Nudge. 1967. Salinity tolerance of seven varieties of creeping bentgrass, Agrostis palustris Huds. Agron. J. 59:335-336. 